\title{
Responding to Disaster with Alternative Education: A Case Study of a Post-disaster Education Project in Bangladesh
}

\author{
Muhammad Ishaq-ur-Rahman \\ School of Geography and Environmental Science, Monash University, Australia \\ mir76bd@yahoo.com
}

\begin{abstract}
The paper presents a case study and lessons learnt from an alternative education project implemented in two cyclone-devastated districts of Bangladesh as a post-disaster response and recovery initiative after the massive cyclone 'Sidr' in November 2007. A survey revealed that the shattered financial condition of local families along with other problems in the formal education system was causing dropouts and non-attendance. Based on the needs assessment the NGO Islamic Relief Worldwide implemented an alternative education project named 'Anondo Biddaloy-Alternative Education for 'Sidr' Affected Children'. In an effort of creating access to the formal education for the drop-out and nonenrolled children, the project focused on regaining and augmenting their interest towards education by offering a learner friendly, joyful education scheme that combined life skills and livelihood skills education with health and wellbeing aspects. Implementation of the project resulted into introducing and retaining a significant number i.e. almost $80 \%$ of its target group in mainstream education. The project thus brought about a major lesson that education with an alternative nature (to the mainstream) can effectively contribute towards ensuring education for vulnerable target groups in a crisis. With an aim of contributing to the academic and practitioner's knowledge of the community relevant to providing education in post-disaster situation, the paper has specific purposes of sharing the concept and contents of the particular alternative education initiative as well as lessons learnt from it.
\end{abstract}

Key Words: Disaster Response, Alternative Education, Bangladesh, Post-disaster, Cyclone Sidr, NonGovernment Organization (NGO), Anondo Biddaloy

\section{Introduction}

Bangladesh has a recurrent past of devastation by natural disasters. On average, a major flood occurs every four to five years, and a severe tropical cyclone hits Bangladesh every three years (MoEF, 2009, GoB 2008). Furthermore, periodic disasters like droughts, river erosion, tidal surges, waterlogged soil, heatwaves, and severe cold along with earthquakes (a concern for potential disasters due to the country's topography) use to occupy the disaster calendar of the country; hence, no month in the disaster calendar of Bangladesh is free from disaster risk (UNICEF Bangladesh 2011, HPN 2010). What is more to ongoing disaster trends in Bangladesh, it has been recognized as one of the most vulnerable countries to Climate Change effect by both the scientific and negotiating community and in future it is likely to face more frequent climatic adversities (MoEF, 2005, 2009). However, the Government with other development stakeholders working for overall preparedness, adaptation and mitigation actions towards environmental catastrophes, education sector of the country is considered to be exposed to environmental mishaps as one of the largest primary education systems in the world, the primary education system in Bangladesh is still largely unprepared to meet disaster challenges (UNICEF Bangladesh 2011). When these environmental mishaps are affecting the overall socio-economic condition of the country, the damage to education services caused by a disaster happens to last much longer than the storms themselves (UNICEF Bangladesh 2011). The UNICEF Bangladesh (2010) statistics gives an idea about the damage caused to education as it reveals that in between 1971 to 2007 over 120,000 primary schools were damaged by floods and 50,000 by cyclones and during 2007-2009 education of more than 1.5 million children have been disrupted particularly by cyclones in Bangladesh. It also reported (in 2010) that only since 2007, about 9000 of Bangladesh's 82000 primary schools had been affected by natural disasters (UNICEF Bangladesh 2011). Along with causing massive humanitarian crisis, disasters are creating significant impact on the country's budget through incurring huge recovery cost. For instance, country's budget had to allocate BDT 11,196 million in just three years- 2004 to 2007 as recovery cost (UNICEF Bangladesh 2010, HPN 2010). 
The evidence with reasonable conjecture of the disasters in Bangladesh in other ways means its Education system is likely to be exposed to more disruption in coming days. Hence, ensuring education in emergencies induced by natural disasters is gradually being recognized as a priority in the Government and development partner's efforts of addressing disaster issues. While government is stepping forward with policy formulation, Non-Government Organizations (NGO's) in the country are taking part by implementing innovative projects alongside undertaking policy advocacy with the Government. This paper with an aim of contributing to the academic and practitioner's knowledge of the community relevant to providing education in post-disaster or emergency situations, presents a summary of such a project entitled "Anondo Biddaloy- Alternative Education for Sidr Affected Children". The specific purposes of this paper are to (1) present the concept and contents of the alternative education initiative in responding to natural disaster; (2) share lessons learnt from the implemented project. "Anondo BiddaloyAlternative Education for Sidr Affected Children" was a post-disaster response intervention implemented by an international NGO-Islamic Relief Worldwide, Bangladesh (IRW, B) during February 2009-January 2010 in two coastal districts of Bangladesh- Patuakhali and Bagerhat. The project locations had their significance as sites among the severely affected areas by the catastrophic cyclone 'Sidr' that hit Southwest Bangladesh in November 2007. IRW, B had launched number of short and medium term interventions in response to the emergency induced by cyclone 'Sidr' e.g. relief and rehabilitation projects immediate after the disaster. In order to contribute into the long-term development of the region, counting on the special situation of the area the NGO then set off the alternative education project. Having a broader objective of developing a healthy and empowered child population among the cyclone survivors the project worked with a specific objective of endorsing a learner friendly and joyful school environment to attract the surviving children to education. To achieve this goal and objective the project catered the target group with offering of safe educational infrastructure, health support and scope for achieving competency to regain access to mainstream formal education.

Project Background: In late 2007, Bangladesh experienced a massive devastation by a tropical cyclone named "Sidr". On the Saffir-Simpson Hurricane Scale, it was measured as category 4, a super cyclonic storm (GoB 2008). It affected upon the lives of a reported 8.9 million people of 2 million families in 30 districts (Fig. 1), with 3347 people killed, 55282 injured and 871 unaccounted for (StC Alliance 2008). Hundreds of national and international Non-Government Organizations (NGO's) including UN humanitarian bodies launched rescue-relief and rehabilitation programs immediate after the cyclone along with the Government. Islamic Relief Worldwide (IRW), one of the world leading humanitarian organizations (headquartered in Birmingham, UK, working in over thirty countries) had also launched multiple projects of short and medium term to participate in that effort. IRW responding disaster induced emergencies in Bangladesh since the devastating cyclone of 1991 through its Bangladesh field office-

\section{Figure 1: Cyclone Sidr affected areas}

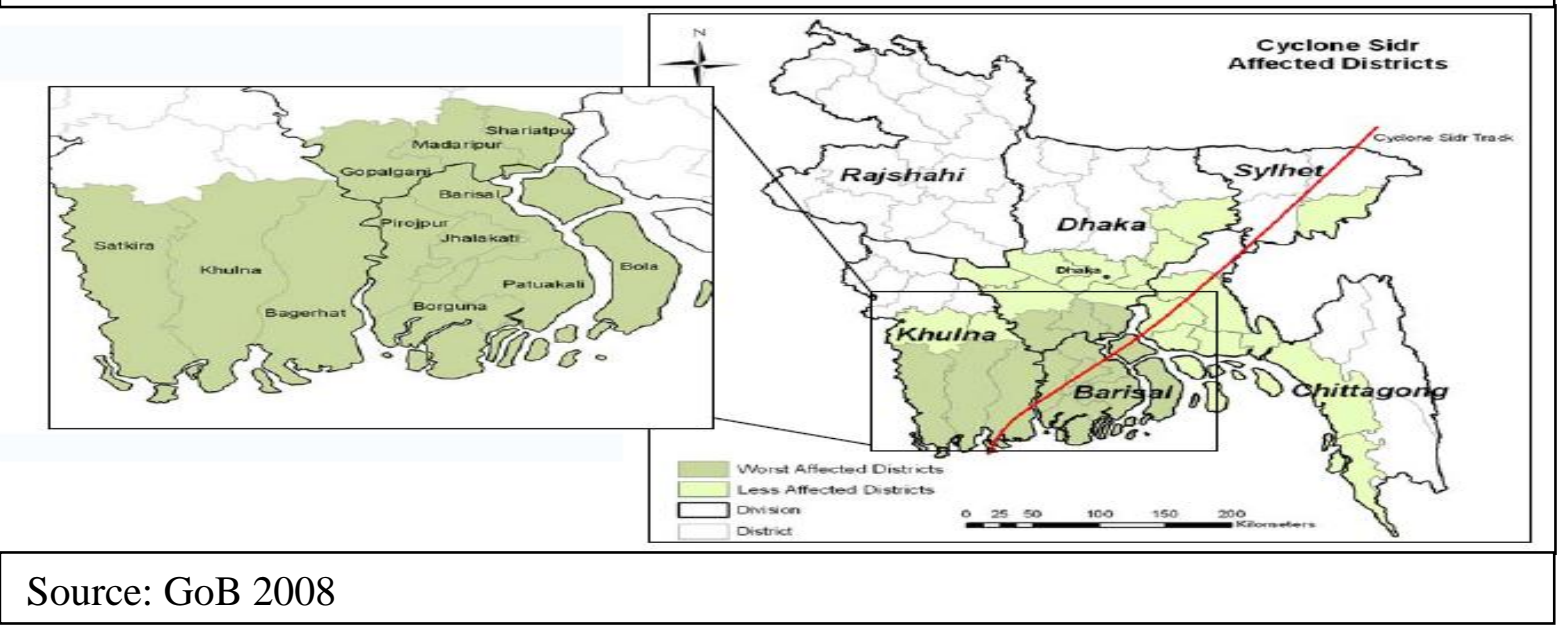

Islamic Relief Worldwide, Bangladesh (IRW, B). Although since the beginning major efforts of IRW,B were 8aimed at relief and rehabilitation of the community in need, it has also been implementing a wide variety of development programs covering the sectors of education and vocational training, water and sanitation, income generation through microfinance, health and nutrition, child welfare etc. Following table (Table 1) presents an overview of the IRW, B programs in Bangladesh: 


\begin{tabular}{|c|c|}
\hline Program Area & Overview \\
\hline Sustainable & It is aimed to identify the community's needs and provide the target group with \\
\hline livelihood & $\begin{array}{l}\text { relevant livelihoods training. Projects include interest-free loans, cash-for-work } \\
\text { schemes and developing small businesses e.g. vegetable and dairy production }\end{array}$ \\
\hline Education & $\begin{array}{l}\text { To provide the impoverished children and young people with low-cost vocational } \\
\text { training in different trades, it has been implementing a project-Vocational } \\
\text { Training and Employment Support Services (VTESS) that operates four } \\
\text { vocational schools }\end{array}$ \\
\hline $\begin{array}{l}\text { Health } \\
\text { Nutrition }\end{array}$ & $\begin{array}{l}\text { Under this program IRW,B has been running a healthcare centre for providing } \\
\text { medication and carrying out health and hygiene training, Mother and Child } \\
\text { Health project for training midwives and traditional birth attendants and an } \\
\text { eyesight restoration project }\end{array}$ \\
\hline $\begin{array}{l}\text { Orphans and Child } \\
\text { Welfare }\end{array}$ & $\begin{array}{l}\text { While primarily facilitating community based orphan sponsorship this program } \\
\text { has a strategic aim to work in wider child welfare issues like child protection, } \\
\text { health care, livelihood development, education etc. of children in need }\end{array}$ \\
\hline $\begin{array}{l}\text { Water } \\
\text { Sanitation }\end{array}$ & $\begin{array}{l}\text { To ensure access of the disadvantaged people to water and sanitation this } \\
\text { program activities included digging wells, building water supply systems, } \\
\text { rainwater-harvesting, constructing latrines and providing basic hygiene training } \\
\text { etc. }\end{array}$ \\
\hline $\begin{array}{l}\text { Emergency Relief } \\
\text { and Disaster } \\
\text { Preparedness }\end{array}$ & $\begin{array}{l}\text { Alongside helping people in all major environmental emergencies (natural } \\
\text { disasters) with immediate relief in Bangladesh, IRW, B is focused on } \\
\text { rehabilitation and long-term development of its target group. Long-term } \\
\text { development projects include Community based disaster preparedness, Local } \\
\text { Disaster Risk Reduction Action Plans, Disaster Preparedness against Risk of } \\
\text { Flood \& Earthquake etc. }\end{array}$ \\
\hline
\end{tabular}

Source: IRW 2012

These broader program areas are covered under concerned departments, respectively called Development Programme (DP), Vocational Training and Employment Support Services Programme (VTESS), Health Programme, Child Welfare Programme (CWP), Water \& Sanitation (WATSAN) Programme and Emergency Disaster \& Preparedness (EDP) Programme.

At the time cyclone Sidr struck, IRW,B however with its different programs had a spatial coverage over 26 districts of Bangladesh (IRW,B 2008-b), as the damage and loss mostly concentrated on the south-west part of Bangladesh (GoB 2008), chose to set up its projects mainly in severely affected areas. Among the 30 districts affected by cyclone Sidr, 8 were recognized as 'Moderately affected' while 4 districts were classified as 'Severely affected' (GoB 2008). Essentially being situated near to the sea and on the path of the cyclone, Bagerhat, Barguna, Patuakhali and Pirojpur were severely affected by cyclone Sidr and the tidal surge occurred due to it. Table 2 shows the major interventions of IRW, B in response to Sidr emergency with area coverage. Most of the responses of IRW, B were focusing immediate rescue and rehabilitation and made through the WATSAN and EDP programs on a short and medium term basis. Hence, in order to bring some longer-term effect in the devastated community it planned some capacity building actions as well under the scope of its other programs like Education and Child Welfare. Accordingly, VTESS program designed Vocational Education (skills development trainings) project for the youth.

While the CWP was carefully observing the broader welfare issues of the cyclone survivor children, it followed one week after the cyclone, UNICEF (2007) reported about one million primary school age children had been affected by the cyclone and about 600,000 children, who were enrolled in primary school, were not having classes and were unable to attend school as their school buildings were destroyed. However, after the catastrophe, majority of the schools had been re-opened in the affected areas and reconstruction of badly destroyed schools had begun by the mid 2008 but school lessons were not happening as normal yet (StC Alliance 2008). Save the Children Alliance (2008) child protection rapid assessment, commenced six weeks after the advent of the cyclone, implied to different issues and concerns around them (Table 3). 
Table 2: IRW,B 'Sidr' response projects

\begin{tabular}{|c|c|c|c|}
\hline Sl & Intervention & $\begin{array}{l}\text { Project Expenditure } \\
\text { (Approx. US\$) }\end{array}$ & $\begin{array}{l}\text { Project Area } \\
\text { (Districts) }\end{array}$ \\
\hline \multicolumn{4}{|c|}{ Project grant received in Cash } \\
\hline 1 & Emergency Food and Shelter (material) & 2552416.00 & $\begin{array}{l}\text { Patuakhali, Jhalokathi, Chandpur, } \\
\text { Bagerhat }\end{array}$ \\
\hline 2 & Water and Sanitation & 168886.20 & Patuakhali, Jhalokathi \\
\hline 3 & Shelter building (household) and reconstruction & 2802911.07 & Patuakhali, Bagherhat \\
\hline 4 & Food and medicine & 20000.00 & Patuakhali, Bagerhat \\
\hline 5 & Food for work & 58475.83 & Jhalokathi \\
\hline 6 & Cash for work & 181138.28 & Patuakhali, Bagerhat \\
\hline 7 & $\begin{array}{l}\text { Capacity building (Vocational education/skills } \\
\text { development training) }\end{array}$ & 19581.00 & Bagerhat \\
\hline & Total & 5803408.38 & \\
\hline \multicolumn{4}{|c|}{ Project grant received in kind } \\
\hline \multirow[t]{2}{*}{1} & $\begin{array}{l}\text { Food and other commodities (hygienic kits like } \\
\text { soap, sanitary napkin, fortified food, rice etc.) }\end{array}$ & 7129224.12 & Patuakhali, Bagerhat, Jhalokathi \\
\hline & Grand Total & $129,326,32.50$ & $(1 \mathrm{US} \$=70 \mathrm{BDT})$ \\
\hline
\end{tabular}

Source: IRW, B 2008-b (compiled)

Table 3: Impacts on children's wellbeing arose off Cyclone Sidr

\begin{tabular}{|c|c|c|}
\hline Issues & & Concern \\
\hline $\begin{array}{l}\text { Children's } \\
\text { emotional } \\
\text { wellbeing }\end{array}$ & & $\begin{array}{l}\text { Evident trauma acquired due to physical ailment, loss of parents, siblings or other family } \\
\text { members obviously affecting the emotional wellbeing and hard to overcome by the children }\end{array}$ \\
\hline Insecurity & & $\begin{array}{l}\text { Potential attack by another natural calamity or intruders at night due to exposed nature of } \\
\text { their temporary shelter and living alone while parents fetched relief, increased number of } \\
\text { 'outsiders' influx in the village (mostly for relief effort though) created security concern to } \\
\text { the children }\end{array}$ \\
\hline $\begin{array}{l}\text { Gender-Based } \\
\text { Violence }\end{array}$ & & $\begin{array}{l}\text { Damage of accommodation and sanitation infrastructures pushing children to live with new } \\
\text { carers while often sleeping in a same bed with extended relatives, absence of safe latrine } \\
\text { compelling adult girls, women to go for toilet in the field after night fall exposed them to } \\
\text { harassment and molestation }\end{array}$ \\
\hline $\begin{array}{l}\text { Access } \\
\text { education }\end{array}$ & to & $\begin{array}{l}\text { An estimated } 25 \% \text { non-enrolment feared to be increased due to joining of a large number of } \\
\text { children in workforce to help family in getting necessary resources and dropout of enrolled } \\
\text { increased as children facing added challenges in entering the formal education system due } \\
\text { to stigma and shame in school, and inability to catch up }\end{array}$ \\
\hline $\begin{array}{l}\text { Economic } \\
\text { exploitation } \\
\text { children }\end{array}$ & of & $\begin{array}{l}\text { loss of family livelihoods evidently pushing marked number of children into range of } \\
\text { dangerous or exploitative labour e.g. factory worker, day labourer (agro, construction), } \\
\text { household help etc. while exposing to financial and emotional abuse, sexual abuse at the } \\
\text { same time }\end{array}$ \\
\hline Migration/ & & Unsupervised and careless child migration to predominantly urban areas for work or joining \\
\hline Trafficking & & $\begin{array}{l}\text { a extended family member due to loss of crops, capital items etc. signalled evident child } \\
\text { trafficking }\end{array}$ \\
\hline Early Marriage & & $\begin{array}{l}\text { This endemic issue feared of having increased appeal to families after the disaster as it could } \\
\text { be a survival strategy (lessening no. of dependant) and also a way of protecting family } \\
\text { honour (lessening chance of being shamed by rape) }\end{array}$ \\
\hline
\end{tabular}

Source: Save the Children Alliance 2008 (adapted)

In their circumstances, to address those emerged issues Child Welfare Program planned to intervene with General Education while integrating broader child welfare issues along with this and consequently developed a comprehensive education project entitled "Anondo Biddaloy-Alternative education for Sidr Affected Children" and submitted to the Islamic Relief Worldwide headquarters fundraising department for marketing. In October 2008, one of the Islamic Relief Worldwide fundraising partners-Islamic Relief Netherlands asked for detail proposal. After review of the Proposal the donor agreed upon implementation of the project from November 2008, however some unavoidable impediment in fund transfer delayed the project launching until February 2009. The project budget was approximately US\$ 84288.32 ( 1 US\$=70 BDT).

\section{Project Concept}

The emergence of the concern of education in post-disaster situation can be traced into the relatively recent theme 'education in emergencies' (EiE). The theme has received prominent attention since 1990 in 
connection with the concept of 'complex humanitarian emergencies', situations that are 'man made' and are often caused by conflicts or civil unrest (Kamel, 2006). Further to 'complex emergencies', the Interagency Network for Education in Emergencies (INEE) defines emergencies along another dimension'natural disasters' that include, among others, hurricanes/typhoons, earthquakes, droughts and floods (Kamel 2006). Hence Save the Children Alliance Education Group defined Education in Emergency as "Education that protects the well-being, fosters learning opportunities, and nurtures the overall development (social, emotional, cognitive, and physical) of children affected by conflicts and disasters" (Sinclair 2002). This definition refers to a comprehensive need for children affected by any emergency. Baxter and Bethke (2009) maintained that children in emergencies require particular set of skills and knowledge to cope up with the surrounding situation of the time however, the range of requirements could vary depending on different context of the emergency and the victims. Save the Children (2008) also suggested of differential context of emergency while they further maintain that a country situations can change rapidly in times of a crisis. A varied context may include aspects like disruption of education due to absence of teachers, loss of materials, infrastructure, acquired trauma by the children due to loss of family, relatives and horrific experience of the catastrophic event, family migration of children, unwillingness (of the dropouts or late- enroller) to join a class with younger children etc. (Baxter and Bethke, 2009, Save the Children, 2008).

While the destruction of necessary educational infrastructure and prevailing low-intensity insecurity may suggest that scope for formal education is confined within some specific spatial boundaries and limited to some grades, Baxter and Bethke (2009) suggested for a variety of educational responses in their circumstances. Uemura (1999) noted that an alternative educational arrangement to the formal education can be endorsed by different stakeholders in such cases. Alternative education refers to all types of nonformal educational arrangement that are out of country's government education system, mostly operated by organizations like NGO's, CBO's etc., doesn't have an automatic validation or certification, ad-hoc and tailor-made to specific observed need and sometimes can work as bridging arrangement to the mainstream formal education (Baxter and Bethke 2009). As mentioned earlier, different context could call for different type of alternative education, like where a specific pandemic is prevalent, an alternative education program could address that issue alongside the formal education, then; a breakdown of a formal education system due to any natural or manmade cause could call for a bridging, transitional education arrangement. In their book containing a comparative study of alternative educations in different context, Baxter and Bethke (2009) classified the alternative education in three major types.

\section{Table 4: Types of Alternative Education}

\begin{tabular}{|c|c|c|}
\hline Sl & Type & Overview \\
\hline \multirow[t]{12}{*}{1} & $\begin{array}{l}\text { Alternative access } \\
\text { program }\end{array}$ & $\begin{array}{l}\text { - Provides an education opportunity to non-enrolled or dropped out children } \\
\text { and youth }\end{array}$ \\
\hline & & $\begin{array}{l}\text { Often operated by NGO's/CBO's to fill the gap of education for particular } \\
\text { groups (e.g. marginalised, victim of an emergency etc.) }\end{array}$ \\
\hline & & $\begin{array}{l}\text { - May follow formal curricula however teachers imparting it may not be } \\
\text { recognized by formal system }\end{array}$ \\
\hline & & $\begin{array}{l}\text { May follow different pedagogical method (e.g. learner cantered) from the } \\
\text { formal system }\end{array}$ \\
\hline & a. Bridging program & One category of access program which: \\
\hline & & enrols mainly missed out or dropped out children \\
\hline & & $\begin{array}{l}\text { is transitional in nature, designed to help the target group to re-enter the } \\
\text { formal system (e.g. accelerated learning program) }\end{array}$ \\
\hline & b. Parallel program & Another category of access program which: \\
\hline & & takes place in a different physical infrastructure than formal school \\
\hline & & enrols mainly marginalized (geographically, racially etc.) people \\
\hline & & mainly managed by the community \\
\hline & & pedagogy is traditional and teachers are untrained and unqualified \\
\hline \multirow[t]{3}{*}{2} & $\begin{array}{l}\text { Alternative } \\
\text { subject/curriculum }\end{array}$ & $\begin{array}{l}\text { Provides education on non-traditional subjects which have a perceived need } \\
\text { for the time }\end{array}$ \\
\hline & Program & $\begin{array}{l}\text { - Can be of relatively short-term in length to bring some behavioural change to a } \\
\text { specific issue (e.g. Landmine awareness program) }\end{array}$ \\
\hline & & $\begin{array}{l}\text { - Also can be long-term intervention to develop an attitude and behaviour to a } \\
\text { particular issue (e.g. HIV/AIDS awareness, environmental education etc.) }\end{array}$ \\
\hline \multirow[t]{2}{*}{3} & Alternative & Adjunct to alternative access or subject program \\
\hline & pedagogy program & Also can be used to upgrade the teaching-learning process of the formal school \\
\hline
\end{tabular}

Source: Baxter and Bethke 2009 (adapted) 
Since starting IRW, B Child Welfare Program has supported its sponsored children's formal education through sponsorship and in 2007 launched an Alternative Subject Program focusing on 'Adolescent Reproductive Health'. This time, based on analysis of the welfare issues arose off the catastrophic cyclone, CWP planned to contribute towards building up a healthy (physically and mentally) and empowered child population among the SIDR survivors through providing basic general education, skills training and health care facilities. Thus, it envisaged an Alternative Access Program, in particular a bridging program that is likely to ensure access of the 'Sidr' survivor children to formal education who were dropped out as well as not enrolled due to different implications of the disaster. The project at the same time enable them to avail better physical and mental wellbeing, empowerment to be resilient to different social issues like insecurity, gender based violence, trafficking etc. as observed.

In perceiving the project concept it was inspired by Basic School System (BSS) of Centre for Mass Education in Science (CMES), a national NGO in Bangladesh working with an aim to arrange an appropriate mass education for the common people encouraging thoughts and actions in science \& technology' (CMES 2012-a). BSS is an established non-formal education model that seeks to provide an effective and practical second chance to disadvantaged dropout adolescent boys and girls for completing their basic education (CMES 2012-b). However, there is a conceptual and structural resemblance (in some cases, like class arrangement, organization of the school day etc.) between 'Anondo Biddaloy' and 'BSS', the basic difference of 'Anondo Biddaloy' concept with 'BSS' is in their goals. While 'BSS' aimed at target group's self-sufficiency and development of social/individual entrepreneurships, 'Anondo Biddaloy' was aimed at creating access for target people to formal education and while doing so it leaves with a potency of self-sufficiency for the eligible target population through skills development. In addition, the programs have different context, while Anondo Biddaloy is a Bridging program, BSS is more like a Parallel program.

Figure 2: Potential input by Alternative education Program

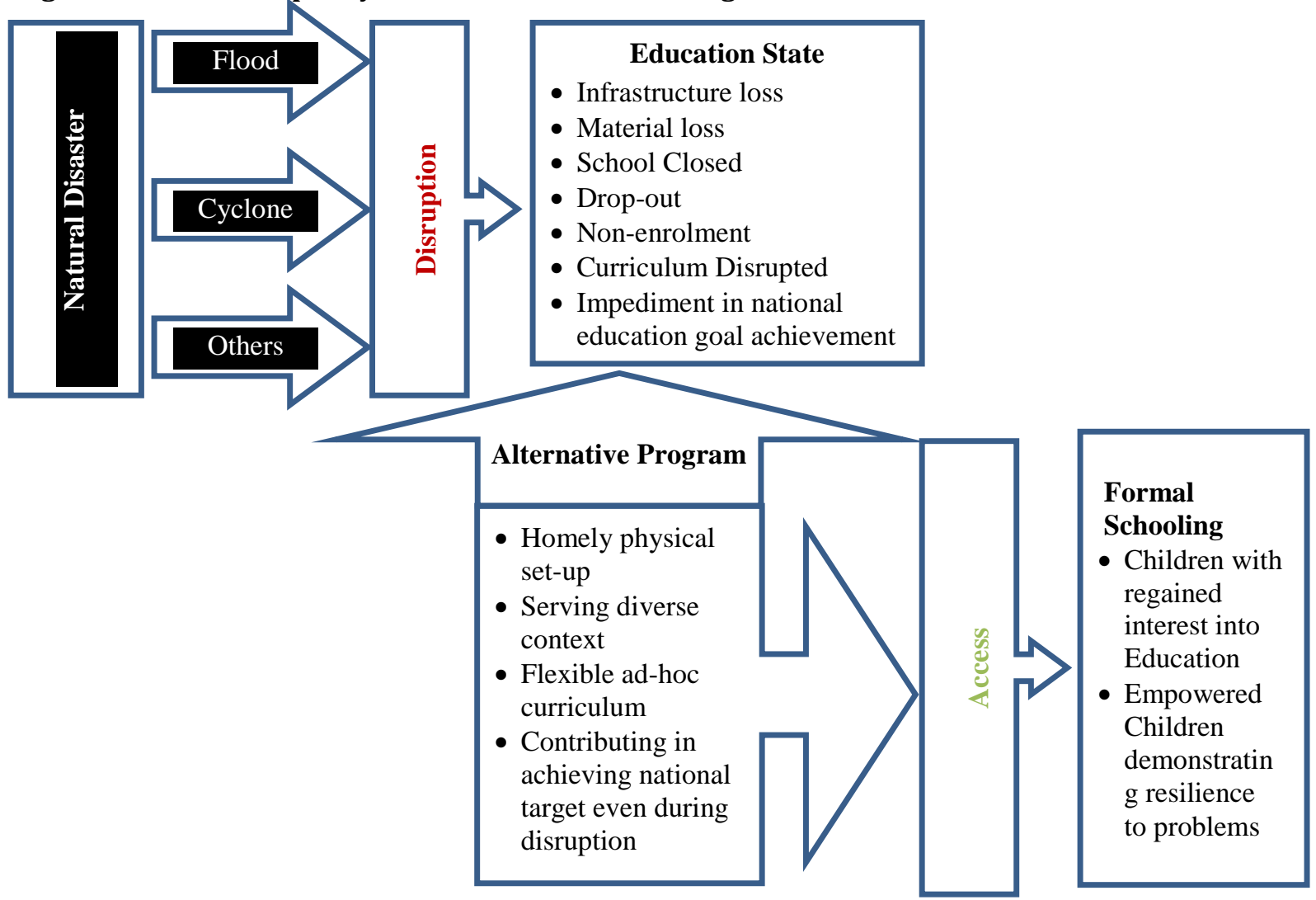

Source: Developed by the author based on IRW, B 2008-a

Bengali words "Anondo Biddaloy" stand for 'A school of joy' ('Anondo' means joy and 'Biddaloy' means school). The concept was to establish a child friendly education setup comprising of services like health support and knowledge of empowerment along with non-formal education that is likely to create access 
for the children distressed (both physically and mentally) by the disaster to mainstream into formal education. By focusing on providing and nurturing the student's competency that would help them to catch up the formal education syllabus when they are enrolled/re-enrolled, Anondo Biddaloy was envisaged as a bridging arrangement for the victim children in gaining access to formal education from a disrupted state of education created by natural disaster. Figure 2 could be a graphical representation of the idea that the project team perceived to develop an alternative access education program. While different types of natural disaster create disruption into the education system, alternative education has the potential to create access/re-access for the victims to formal schooling again. The unique and flexible attributes of it can ensure both physical access and access to one of the most important human rightseducation for people in a crisis.

\section{Project Location}

In compliance with the IRW, B strategic plan of working in the worst affected areas, Morelganz and Shoronkhola upazila of Bagerhat district and Galachipa upazila of Patuakhali district were decided as project location. The project area was spread across 12 Unions of two districts (Fig. 3):

\section{Case Study Analysis}

Project Contents and Outputs: As per the concept and proposal, the project activities were divided into two major categories, i.e. Preparatory Activity and Execution Activity. The project developed an overall work plan based on which the Project Officers used to plan for the monthly activities and required resources. To measure the project output primarily a Project Officer used to produce a Monthly Report for his area and then the coordinating Program Officer of CWP used to compile the both areas report monthly quarterly and annually to assess against expected outputs. In addition, the project produced an interim and a project completion report (both technical and financial).

Preparatory Activity: These were the activities required for setting up the project and included activities like staff recruitment, conducting a base-line survey and setting up the physical structure of the Anondo Biddaloy schools.

\section{Figure 3: Project Location}

\begin{tabular}{|c|c|c|c|c|c|}
\hline \multirow{13}{*}{ Prolect location man } & S1 & District & Upazila & Sl & Union \\
\hline & 1 & Bagerhat & Morelganj & 1 & Baroikhali \\
\hline & & & & 2 & Boloibunia \\
\hline & & & & 3 & Morelganj Sadar \\
\hline & & & & 4 & Khaulia \\
\hline & & & & 5 & Nishanbaria \\
\hline & & & Shoronkhola & 6 & Khontakata \\
\hline & 2 & Patuakhali & Galachipa & 1 & Galachipa Sadar \\
\hline & & & & 2 & Panpotti \\
\hline & & & & 3 & Amkhola \\
\hline & & & & 4 & Golkhali \\
\hline & & & & 5 & Dakua \\
\hline & & & & & Pourashava \\
\hline
\end{tabular}

Source: IRW, B 2008-a

- $\quad$ Staff Recruitment: It was the first activity and one of the most challenging ones as the project required its own staff that necessarily should be local in order to organize and implement the diverse range of activities engaging with the local community and other stakeholders. 20 teachers for 20 schools, 1 Project Officer for each of the project area and 1 accountant for the project, in total 23 project staff were recruited. For recruiting teacher, job advertisement was made in local level and a good response was received. However, in selecting teacher finally emphasis was given on prior experience of teaching/tutoring with children. Project Officers were recruited based on their prior experience of leading implementation of development project. All the project staff recruitment followed standard IRW, B human resource recruitment protocol i.e. through a written exam and oral interview. A Program Officer 
from CWP of IRW, B was assigned to develop the concept and proposal of the action initially and then as the coordinator of the project. He was also responsible to ensure resource mobilization, lead material development and implementation of all the planned project activities and report to the Program Manager of the CWP, Country Director of IRW,B and as well as to the donor about the project progress.

- $\quad$ Base-line survey: A base line survey was conducted by the project in February 2009 to collect the socio-economic information of target children and their families to assess the children's specific need. Survey participants were primarily selected from a Focus Group Discussion (FGD) and then using a snowball method (reference from the primarily selected target families). Thus, 690 (Morelganj 395+ Galachipa 295) household had been surveyed. The survey revealed that being mostly engaged in informal economic activities (30\% day labourer in agricultural or other different sectors, $25 \%$ in farming, $15 \%$ fisherman) around half of the respondent families had an average monthly income of only US $\$ 35$ (during the survey time) to support a fairly big family ( $45 \%$ family consisting of 6-10 members, rest 1-5). The cyclone devastated the national and regional economy in such a way that the families were struggling for earning livelihoods, where education for children became very less important and this was resulting into school dropout for once enrolled and non-enrolment for eligible school goers (IRW,B 2009-b, CWP 2010). Only $5 \%$ of the respondent family had moderate knowledge on health (and avail access to health care facilities) and hygiene issues and rest have no knowledge at all. It also explored less than $1 \%$ children used to take any food other than major meal that can be considered as supplementary diet and none of the children in the surveyed households had any trade skills which could give them a confidence of having some livelihood skills to use in need (IRW,B 2009-b). Survey findings were used to devise the activities more accurately and at the same time to locate the potential most accessible location (for the children) for setting up Anondo Biddaloy schools.

- $\quad$ Anondo Biddaloy School set-up: Anondo Biddaloy schools served as pivotal point for delivering project deliverables. The project established 20 "Anondo Biddaloy" schools, 10 in Bagerhat and 10 in Patuakhali districts. Most (16 out of 20) of the school premises were given by the community as free while few others were rented. Those were mostly the out houses not in frequent use by the owners. While choosing the location of school premises preference had been given to ensure closer access to maximum number of the students. The schoolroom had been furnished with economical though children friendly furniture, for example, instead of desk-chair or bench (usually used in formal schools) 'Jute (natural fibre) rug' was used, however, this could be common like some other non-formal schools operated by NGO's but different from formal government schools. This arrangement (location and infrastructure) offered closest possible access to a school, a more homely and non-formal educational environment for the children.

Execution Activity: Execution activities included activities for staff capacity building, project launching, project implementation, monitoring and evaluation, reporting and activities to ensure project visibility.

- $\quad$ Staff Capacity building: Staff capacity building was a very important issue for the project as the school teachers were not merely responsible to teach in school rather a whole range of activities like surveying for students, networking with community people, local leaders, government officials and educational institutions, monthly reporting on planned activities, purchasing different type of materials, event management etc. were also part of their daily duties. On the other hand, the Project Officers needed to understand the underlying issues related with the alternative schooling apart from their regular administrative duties. Therefore, the staff required to develop an insight on the project and in order to give the staff a familiarity with the project spirit and overall IRW, B culture of project implementation, the project started with an induction program arranged centrally. The project also had staff foundation training and periodical refreshers training imparted by Child Welfare Program. A comprehensive teacher's guide book for the teachers was developed and made handy to them which contained detail explanation of the curriculum, syllabus, class routine and how to conduct the class, how to operate every day activities of an Anondo Biddaloy school.

- $\quad$ Community mobilization and participation: Field level implementation of the project started with a formal community mobilization meeting in both areas. Concerned government officials, representatives of local government bodies from 12 Union, local elites, diverse professionals attended meeting where they were informed about the project in details and approached for possible support from their side. Also informal mobilization meeting was organized in the village level (where preliminary space for school had been selected) in participation of the potential student's parents, local elites, representative from local governments etc. This attracted huge community participation. Besides providing free space for school, community people also engaged themselves in monitoring of the school program by forming a formal 'Local Support Group (LSG)' for each school. LSG was comprised of 7 members (included local elites, parents, local government representatives while respective schoolteacher supported with secretarial 
activities) who used to monitor the school operation and document the findings by filling up a monitoring format. They used to meet on a monthly basis to discuss on their findings where they used to suggest their recommendations for necessary development of school program (like maintaining timeliness for school activities, ensuring students attendance etc.) and for rendering necessary support for the schools as well. 20 LSG has organized 165 meetings in two areas (IRW, B 2010).

- $\quad$ Academic structure of Anondo Biddaloy: An Anondo Biddaloy school was devised with two classes 'Sikhon' (Learning) and "Goron' (Developing), both containing 15 students and one teacher per school. Thus, there had been enrolled 600 children in total where total no. of teacher was 20. Following table (Table 5) shows the overall structure:

Table 5: Academic Structure of Anondo Biddaloy

\begin{tabular}{|c|c|c|c|c|c|}
\hline Class & $\begin{array}{l}\text { No. of } \\
\text { Student/School }\end{array}$ & No. of School & $\begin{array}{l}\text { Total } \\
\text { Student }\end{array}$ & $\begin{array}{l}\text { No. of } \\
\text { Teacher/School }\end{array}$ & $\begin{array}{l}\text { Total } \\
\text { Teachers }\end{array}$ \\
\hline Sikhon & 15 & & 300 & & \\
\hline Goron & 15 & 20 & 300 & 1 & 20 \\
\hline Total & 30 & 20 & 600 & 1 & 20 \\
\hline
\end{tabular}

Source: IRW, B 2009-a

- $\quad$ Students were enrolled in a class based on their age. Sikhon class enrolled children aged 5-9 years while children aged 10-16 years were enrolled in Goron class. Though it could sound unusual to have classes of such a diverse range of age, as the schooling was opted to help regaining the confidence and interest in education for the children rather than asserting any formal qualification to them, the project bunch the primary education aged children and secondary education aged children in two single classes.

- $\quad$ Curriculum and Syllabus: The curriculum, developed by the project team, was focused on providing the student with an overall competency rather than grade specific (formal schools) literacy. However, the subjects were chosen mostly in line with formal schools grade/class and it also followed some teaching materials of formal school as well, the curriculum and syllabus was focused to give the children a practical knowledge base. As the students of an Anondo Biddaloy class were of different ages who were supposed to be in different formal school grades, the curriculum allocated a common and general competency requirement for the primary level (Sikhon) and secondary level (Goron) based on the review of the expected outcome of the literacy of formal school classes (CMES has successfully used this method). The following table (Table 6) presents a summary of the curriculum:

Table 6: Curriculum and Syllabus for Anondo Biddaloy

\begin{tabular}{|c|c|c|c|}
\hline Class & Sikhon & & \\
\hline Subject & Curriculum & Semester & Syllabus aiming competencies \\
\hline \multirow[t]{8}{*}{ General Education } & Language: Bengali & $1^{\text {st }}$ and $2^{\text {nd }}$ & $\begin{array}{l}\text { Learning letters and rhymes, reading and making } \\
\text { small words, reading and making sentences }\end{array}$ \\
\hline & Language: English & $1^{\text {st }}$ and $2^{\text {nd }}$ & $\begin{array}{l}\text { Learning letters and rhymes, reading and making } \\
\text { small words, reading and making sentences }\end{array}$ \\
\hline & Mathematics & $1^{\text {st }}$ and $2^{\text {nd }}$ & $\begin{array}{l}\text { Counting, simple maths, introduction to financial } \\
\text { calculation }\end{array}$ \\
\hline & General Knowledge & $1^{\text {st }}$ and $2^{\text {nd }}$ & $\begin{array}{l}\text { Information and statistics about Bangladesh and } \\
\text { World }\end{array}$ \\
\hline & Practical Science & $1^{\text {st }}$ and $2^{\text {nd }}$ & $\begin{array}{l}\text { Different experiment on light, thermal, fluid, } \\
\text { magnetic dynamics, making shapes with } \\
\text { modelling clay }\end{array}$ \\
\hline & $\begin{array}{l}\text { Disaster Preparedness } \\
\text { and Response }\end{array}$ & $2^{\text {nd }}$ & $\begin{array}{l}\text { Different disaster, how and when they usually } \\
\text { may occur, what to do during a particular } \\
\text { disaster }\end{array}$ \\
\hline & Drawing & $2^{\text {nd }}$ & Shapes, figures \\
\hline & Health Education & $2^{\text {nd }}$ & General health care \\
\hline Trade Education (At & Tailoring & $1^{\text {st }}$ and $2^{\text {nd }}$ & Technical know-how of the production process, \\
\hline $\begin{array}{ll}\text { least } & \text { one } \\
\text { trade/student) } & \end{array}$ & $\begin{array}{l}\text { Book Binding } \\
\text { Candle Making }\end{array}$ & $\begin{array}{l}1^{\text {st }} \text { and } 2^{\text {nd }} \\
1^{\text {st }} \text { and } 2^{\text {nd }}\end{array}$ & knowledge about relevant raw materials, market \\
\hline $\begin{array}{l}\text { Participating } \\
\text { School operation }\end{array}$ & $\begin{array}{l}\text { Extra-Curricular } \\
\text { activities }\end{array}$ & $1^{\text {st }}$ and $2^{\text {nd }}$ & $\begin{array}{l}2 \text { students/semester elected by students to form } \\
\text { School Operation Committee, help teacher in } \\
\text { school day to day operation }\end{array}$ \\
\hline Social Initiative & & $1^{\text {st }}$ and $2^{\text {nd }}$ & $\begin{array}{l}\text { Decide through School Operation Committee } \\
\text { meeting and initiate at least } 1 \text { initiative every } \\
\text { fortnight }\end{array}$ \\
\hline Sports & & $1^{\text {st }}$ and $2^{\text {nd }}$ & Indoor games depending on facilities available \\
\hline
\end{tabular}




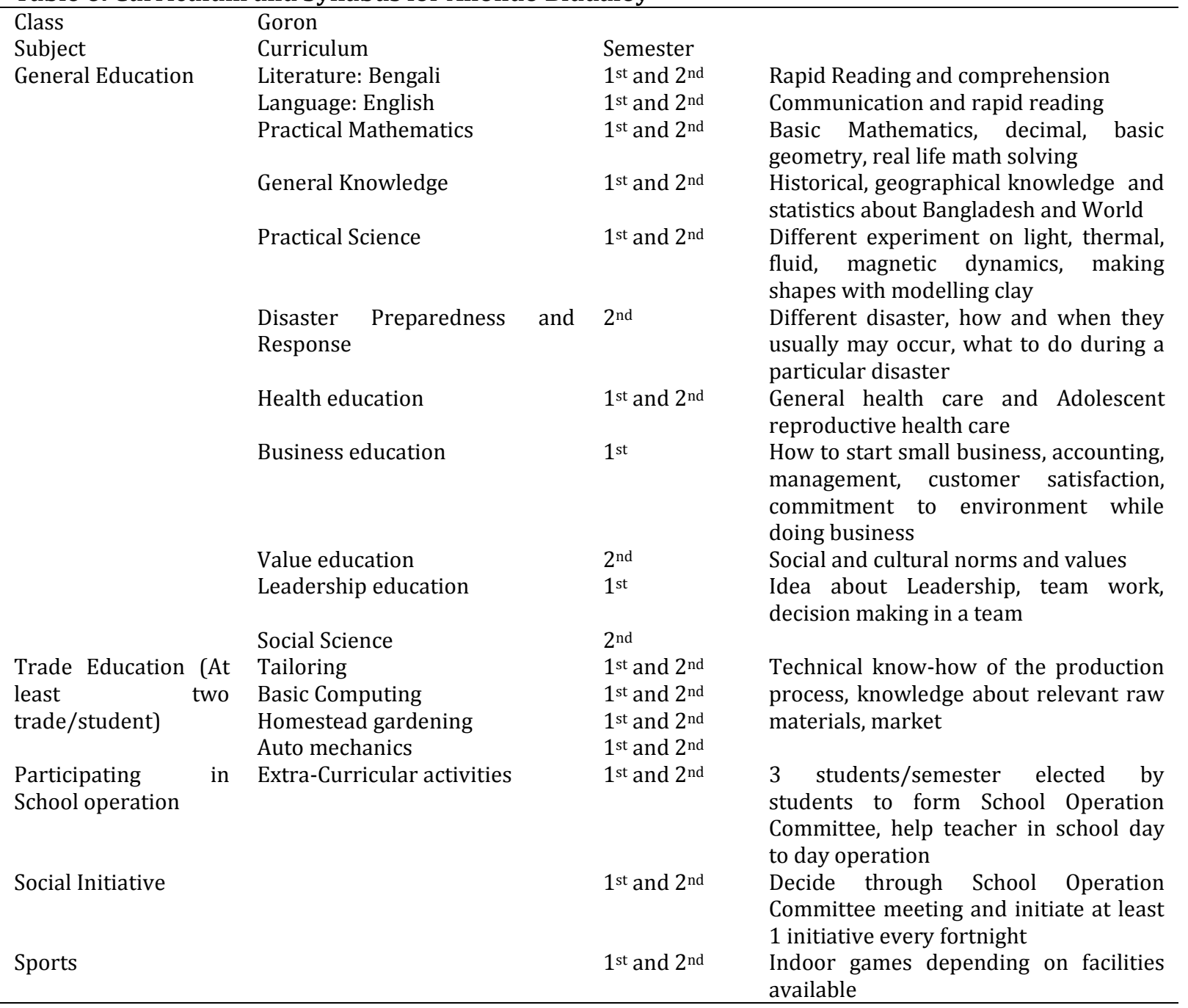

Source: Rahman, 2009

The academic year was divided into two semesters and again each semester was divided into two quarters. A quarterly evaluation of the achievement of the syllabus helped to monitor the achievements. All these helped to maintain equivalence with the formal school education despite it was non-formal in nature. Also notably, the project provided students with all necessary reading and writing materials, school bag, uniform free.

- $\quad$ Class management: A unique child-centred teaching-learning method had been endorsed by the project that enabled one teacher to maintain two classes at the same time and maintain different other administrative activities. The curriculum and class routine had been devised to ensure this. First and most important was that the achievement of the required competency was designed to have through proactive participation of the children. For this, the teachers were trained to impart the curriculum through activities rather than usual lecture method followed in the formal schools of Bangladesh. For example, where the expected competency was that the children would learn to make words consisting three letters, teacher might divide them in groups and engage them in a game of 'as many words as a group can make' within a certain period. In addition, the assessment later would be done by the peers. This method of activity-based teaching engaged the children most that required teacher's presence as mere facilitator. In addition, the whole class was divided into small peer-groups. A group contained of five students where there was a mix of good and relatively poor students. One person used to be the group leader. This worked in two ways, it brought a balanced state of learning and the group leader used to ensure the presence of his/her peer group member that ensured a higher attendance rate in school. The group leader's role as peer-educator (for mentoring group members) substituted teacher's presence in every class. The class routine was devised based on this flexibility. However, the teaching period of two classes were divided in such a way that when one class would attend general education facilitated by the 
teacher then another class would do some science experiment with their mini portable science lab or play indoor games or learn some livelihood skills (for say garments making) supervised by the peer-educators or skills training instructor and vice versa. Thus, the effort given to establish the children's authority in the school ensured by the curriculum enabled attaining 273 days of general education class with on an average $95 \%$ attendance of the students (IRW, B 2010).

- $\quad$ Health support: However, health care facilities are not part of education system in Bangladesh (neither in formal nor in non-formal education), the project had health care support component for couple of reason. Firstly, as evident need for physical and psychological support for the cyclone survivor children was established through the research by organization like Save the Children and by the base-line survey done by this project. Secondly, all the initiative by CWP has an inbuilt health support component, which depicts its strategic aim for ensuring balanced child welfare. To ensure the health (both mental and physical) improvement of the children enrolled, there had been arrangement for regular monthly health check-up session, providing necessary prescribed medicine, de-worming medicine and vitamin-A supplementation twice a year and regular Tiffin during school days under this component. In order to provide health support 4 Doctors were contracted in Galachipa and 1 in Morelganj who operated 9 'Health Session' (IRW, B 2010) in each area that included service like counselling, basic health check-up, referral and medicine prescription where necessary. Under this component 765 students received free prescribed medicine, 594 children received de-warming and vitamin-B medicines twice during the project period and 111,437 numbers of children (cumulative no.) received supplementary food like fruits, egg, cake biscuit etc. during the school days (IRW,B 2010).

- $\quad$ Livelihood Skills development: The students, who were able and eager to gain some livelihood skills, had been provided with skills training like basic computer training, tailoring (garments making), agricultural training (homestead gardening) etc. For this, two areas (Morelganj and Patuakhali) were equipped with two computer labs (consisting 7 computers) and 14 sewing machines based in different schools for skills training. While aimed to develop self-dependency and empowerment among the children, this component arranged skills training in above-mentioned trades for 537 numbers of children, 260 from Morelganj and 277 from Galachipa (IRW, B 2010).

- $\quad$ Life-skills education: The school curriculum included different life skills focused education for the children. To grow up managerial capacity and leadership among the children each school formed a 'School Operation Committee (SOC)' containing students from the school that helped the teachers in managing the school properly. Each SOC was comprised of 5 members selected (in some schools also elected) by the fellow class mates and vested with specific responsibility for example School's physical environment management, Event management etc. The committee had regular meeting to discuss about necessary issues in school operation and plan for community development work. Thus the committee also lead in 114 social and community development work (IRW,B 2010) ranging from activities like tree plantation, campaign against early marriage and dowry, cleanliness campaign, voluntary road repairing etc. The schoolchildren organized themselves to observe two national day of significance National Independence Day (26 March) and World Mother's day during the project period to focus on specific issues like commitment to the nation and society, family, need for safety, recreation for the children etc. This effort also mobilized the community people.

- $\quad$ Recreation: Recreation with indoor games was in-built within the curriculum. All the schools were equipped with a mini portable lab for science experiments (Science kit box) 5 items of indoor games materials. Besides, one annual sport, one excursion and one picnic had been arranged for all of the students to provide a recreational window in the schooling.

- $\quad$ Networking and Advocacy with formal school: Project staffs were indulged in formal and informal networking and advocacy with formal educational institutions of the adjacent area throughout the project period. As part of this activity, the teachers and Project Officers used to visit the nearby formal schools and Madrasha (religious educational institute) and meet with the teachers to discuss about the project and possible placement of their students after the project is over. The teachers of formal school also visited the schools to understand the education process and student's progress. Networking with the Government Education Officers of the concerned area by the CWP staff and Project Officers, coordination with other NGO's working in the same sector also augmented a wider awareness and acceptance about the project and its objective. This along with other effective project inputs finally resulted into enrolment of 444 children out of total 600 enrolled in formal educational institutions. Out of 444 children, 198 were enrolled for the first time i.e. in grade 1 and rest 246 were re-enrolled in grade 2-9 (IRW, B 2010). 


\section{Outcomes /Impact of the Project}

By creating access to formal education for almost $80 \%$ (444 children out of 600 ) of the enrolled project participants, the project brought a successful result in two ends. First, to the project end, while it demonstrates the project's success in endorsing a learner friendly and joyful school environment to attract the surviving children and adolescents to overcome the trauma they had and regularizing them in education once again. Second, to the regional education sector end, as it at the same time demonstrated its potential in retaining and introducing a significant number of primary aged children in education after the cyclone (it was significant as child protection rapid assessment by Save the Children Alliance in 2008 estimated a $25 \%$ further increase of non-enrolment on top of the existing rate). Further to capture the achievement of the project, it is worth analysing the expected results set to be achieved to attain the project objective. The project completion report maintained of achieving following three results:

- A safe and secured school environment was established to bring confidence among the students for regular school presence- The schools being endorsed with child friendly physical and academic environment were highly successful to grow an interest of regular schooling among the project participants. Despite of interruption by another cyclone in the middle of the project, conduction of 273 days of schooling with on average 95\% attendance of the students (IRW, B 2010) indicates the success of the schools as safe and secured educational harbour.

- Children and adolescent grew as healthy (both physically and mentally) and cheerful- Achievement of this result has been measured through the attainment of the outputs like number of health and awareness session held, number of children received free medicine, de-warming and vitamin supplementation, supplementary food, number of items of indoor games facilities provided and sports and picnic organized.

- Capacity of the children has been built- The project worked towards building and improving capacity of the children in different ways like by enabling them to pursue a livelihood skill, growing selfesteem within them. Development of skill (in trades like Tailoring, Basic Computing and Homestead Gardening) tends to bring a sense of security among the children such a way that they showed confidence of supporting their educational cost if parents are unable* (Rahman \& Rahman 2010). Formation of 20 School Operation Committee (SOC), successful operation of committee evident through observation of days of significance (to focus on specific child development issues) and undertaking social works in the locality ranging from activities like tree plantation, campaign against early marriage and dowry, cleanliness campaign, voluntary road repairing etc. demonstrate developed leadership and self-esteem among the enrolled children.

Lessons Learnt: The project brought some valuable lessons for the implementing organization, which are worth sharing, as it is likely to be of interest to the practitioners; major lessons were as follows:

- The initial attendance rate shows that regularizing the once dropouts and new enrolled (particularly in a post disaster period) in school again is really challenging, however, alternative education arrangements (offering health care, teaching materials, supplementary food, recreational

* Munni Wishes to Rebuild Her Life
... Before Sidr had struck, Munni was a student of class-iv in Golachipa Model Primary School. However, since
the cyclone, they lost their home and other belongings. Her father had to work hard to arrange a small home on
the riverbank. Gradually he started a tea-stall to meet the ends. However, that earning was not enough to allow
him send Munni back to school again. However, when he heard about Islamic Relief's program in their area, he
immediately admitted Munni in the Goron (Developing) level in Shyamolibaag Ananda Bidyalay. Munni started
her education once again.
Munni was always a meritorious student. She made her mark at Ananda Bidyalay as well. She was a regular
student too. From the livelihood skills, she chose tailoring as her training course. After completing her education
there, Munni wanted to continue her education further. Therefore, she took an admission test at Golachipa Girls
High School and successfully was admitted in class-vi there. She hopes that she will complete her high schooling
with success and then get into a college for higher education. Munni is good at tailoring (garments making) as
well. She is making good use of her learning from the training course and taking orders from neighbourhoods.
She is using her small earning to support her educational costs. Munni's parents are proud of the way she is
determined to rebuild her life following the setback of cyclone Sidr.
Ms. Munni Akhter
Shyamolibaag Anondo Biddaloy,
Upazila-Golachipa, District-Potuakhali, Bangladesh


facilities, engaging student's in school operation etc.) can ensure higher attendance and enrolment in school even in a post-disaster situation

- Incorporating community members in school monitoring can help in better student attendance. Focusing on attendance issue while regular meeting of the Local Support Groups essentially helped in attaining guardian's attention to ensure child's school presence

- $\quad$ Providing skills training along with general education can make the disadvantaged children to feel empowered and confident to continue education

- Organized information dissemination to the stakeholders about a project (for example this project undertook project inauguration, project completion meetings, monthly support group meeting etc.) can ensure better participation and support of the stakeholders

- $\quad$ Networking with formal educational institutions, local level government education department is necessary for mainstreaming of dropped out children

- While developing a relatively short project like this twelve month one, duration or length of activities should be planned more carefully to make the full achievement

- $\quad$ For short term projects, training outsourcing for skills development of the participants is better and cost effective than setting up facilities by the project

- Arranging Health care facilities in the remote project areas are far more complicated than anticipation due to lack of qualified doctors

- $\quad$ Such project can bring synergy to overall organizational operation. For example, the working areas and the most of the beneficiaries survived another Cyclone "AILA" (in 2009) during the project period. Prior to any Islamic Relief Worldwide, Bangladesh office action for recovery in that disaster, this project got itself involved with its regular healthcare service, medical care and supplementary feeding as response to the emergency

- $\quad$ The project could conduct the needs assessment and base-line survey more comprehensively which could initiate more logical intervention, also conducting a project end survey could help to measure the project impact in a more scientific way

- $\quad$ The organization had scope for undertaking the project as an Action Research for setting up future strategic goal for working in post-disaster situation with education intervention

- $\quad$ The project could use its image of success to take the opportunity to transform education system (Baxter and Bethke 2009) if further funded, however lack of organizational strategic aim in area like education in emergency made it an one time implemented project

\section{General Conclusion}

Though the project was implemented about one year after the catastrophe, it was actually devised immediate after the cyclone. The base-line survey also did not suggest too changed a context than the aftermath of the disaster. The project was a different kind of initiative by the organization that was mainly indulged in food, shelter, medical and livelihood oriented rehabilitation in a post-disaster situation. The project lessons and success implies the need and usefulness of such initiative and at the same time beg for careful judgement of its value in the relevant academic school of thought and wider context of disaster response practice for developing countries like Bangladesh.

Recommendations: In order to ensure that the children do not lose a single day due to emergency and lack of preparation, education in a post-disaster situation should be steadfastly integrated in the disaster preparations (UNICEF Bangladesh 2010). Incorporation of such intervention in the strategic plan of the organizations working in emergency response and rehabilitation might result in immediate and more organized response. Piloting of actions like this in increased number is needed for that. This may lead towards establishing handy model/s of education in a post-disaster period that might be replicable in such situation in any region, by any organization within the country or in a country context similar to Bangladesh. Following the gap of academic research in this area, a research to explore whether 'Alternative Education' can be a useful measure to response emergencies in Bangladesh can be undertaken. This case study could be useful in this relation. Further analysis of this case study in light of the current international development theory and practice of alternative education in a post disaster situation could help to answer the question. At the same time, it could help to establish this action as a potentially replicable model by shaping it up with international practitioner's and academic knowledge.

Acknowledgement: Author is greatly indebted and thankful to Dr Bruce Missing ham, Lecturer at SGES, Monash University, Australia and anonymous reviewers for their valuable time and guiding comments 
that helped to present the case study in this acceptable form. The author was the team leader for developing and implementing the project and would like to acknowledge the contribution of the team members.

\section{References}

Baxter, P. \& Bethke, L. (2009). Alternative Education: Filling the Gap in Emergency and Post-conflict Situations. International Institute for Educational Planning, France and CFBT Education Trust, UK.

Centre for Mass Education in Science (CMES). (2012 a). Welcome to Centre for Mass Education in ScienceCMES. Retrieved April 28 2012, from http://cmesbd.org/

Centre for Mass Education in Science (CMES). (2012 b). Basic School System. Retrieved April 28, 2012, from http://cmesbd.org/

Government of Bangladesh. (2008). Cyclone Sidr in Bangladesh- Damage, Loss and Needs Assessment for Disaster Recovery and Reconstruction. Retrieved July 5, 2008, from www.gfdrr.org

Humanitarian Practice Network (HPN). (2010). Education in Emergencies. HPN Event Reports. Retrieved October 25, 2011, from http://www.odihpn.org/hpn-resources/hpn-event-reports/educationin-emergencies

Islamic Relief Worldwide (IRW). (2012). What We Do. Retrieved April 28, 2012, from http://www.islamic-relief.com/whatwedo/Default.aspx?depID=3

Islamic Relief Worldwide, Bangladesh (IRW, B). (2010). Project Completion Report, Anondo BiddaloyAlternative Education for SIDR Affected Children. Unpublished report. Child Welfare Programme (CWP). Islamic Relief Worldwide, Bangladesh.

Islamic Relief Worldwide, Bangladesh (IRW, B). (2009a). Project Proposal on Anondo BiddaloyAlternative Education for SIDR Affected Children. Unpublished report. Child Welfare Programme (CWP). Islamic Relief Worldwide, Bangladesh.

Islamic Relief Worldwide, Bangladesh (IRW, B). (2009b). Base Line Survey Report Anondo BiddaloyAlternative Education for SIDR Affected Children. Unpublished report. Child Welfare Programme (CWP). Islamic Relief Worldwide, Bangladesh.

Islamic Relief Worldwide, Bangladesh (IRW, B). (2008a). Concept paper on Anondo Biddaloy- Alternative Education for SIDR Affected Children. Unpublished document. Child Welfare Programme (CWP). Islamic Relief Worldwide, Bangladesh.

Islamic Relief Worldwide, Bangladesh (IRW, B). (2008b). Annual Report (Draft)

Kamel, H. (2006). Early childhood care and education in emergencies. Paper commissioned for the EFA Global Monitoring Report 2007, Strong foundations: early childhood care and education

MoEF. (2009). Bangladesh Climate Change Strategy and Action Plan 2009. Ministry of Environment and Forests, Government of the People's Republic of Bangladesh. Dhaka, Bangladesh. pp. xviii+76

MoEF. (2005). National Adaptation Programme of Action (2005). Ministry of Environment and Forests, Government of the People's Republic of Bangladesh. Dhaka, Bangladesh. pp. xvi+46

Rahman, M. I. \& Rahman, S. (2010). A Joyous Retreat: Selected Success Stories from Anondo Biddaloy Project. Child Welfare Programme (CWP). Islamic Relief Worldwide, Bangladesh. pp. IV+42

Rahman, M. I. (2009). Sikhok Nirdeshika. Unpublished Teacher's Manual (in Bengali). Child Welfare Programme (CWP). Islamic Relief Worldwide, Bangladesh.

Save the Children. (2008). Delivering Education for Children in Emergencies: A Key Building Block for the Future. International saves the Children Alliance, Cambridge House, and London, UK

Save the Children Alliance. (2008). Child Protection Rapid Assessment Sidr affected areas, Bangladesh

Sinclair, M. (2002). Planning Education in and after Emergencies. Paris: UNESCO, p. 81.

Uemura, M. (1999). Community Participation in Education: What do we know? Washington DC: World Bank.

UNICEF Bangladesh. (2011). Education in Emergencies and Post-Crisis Transition. 2010 Report Evaluation. Retrieved July 2, 2011, from www.unicef.org

UNICEF Bangladesh. (2010). Ensuring education of children during emergency is a priority. Retrieved June 6 2011, from http://www.unicef.org/bangladesh/media_6152.htm

UNICEF (2007). Cyclone Sidr Bangladesh Situation Report - EXTERNAL (22 November 2007). Retrieved April 2, 2008, from www.unicef.org 